\title{
A national methodology to quantify the diet of grazing dairy cows
}

\author{
D. O’Brien, ${ }^{* 1}$ B. Moran, $\dagger$ and L. Shalloo* \\ *Livestock Systems Department, Animal and Grassland Research and Innovation Centre, Teagasc, Moorepark, Fermoy, Co. Cork, \\ Ireland P61C997 \\ †Rural Economy Research Centre, Teagasc, Athenry, Co. Galway, Ireland H65R718
}

\section{ABSTRACT}

The unique rumen of dairy cows allows them to digest fibrous forages and feedstuffs. Surprisingly, to date few attempts have been made to develop national methods to gain an understanding on the make-up of a dairy cow's diet, despite the importance of milk production. Consumer interest is growing in purchasing milk based on the composition of the cows' diet and the time they spend grazing. The goal of this research was to develop such a methodology using the national farm survey of Ireland as a data source. The analysis was completed for a 3-yr period from 2013 to 2015 on a nationally representative sample of 275 to 318 dairy farms. Trained auditors carried out economic surveys on farms 3 to 4 times per annum. The auditors collected important additional information necessary to estimate the diet of cows including the length of the grazing season, monthly concentrate feeding, type of forage(s) conserved, and milk production. Annual cow intakes were calculated to meet net energy requirements for production, maintenance, activity, pregnancy, growth, and live weight change using survey data and published literature. Our analysis showed that the average annual cow feed intake on a fresh matter basis ranged from $22.7 \mathrm{t}$ in 2013 to $24.8 \mathrm{t}$ in 2015 and from 4.8 to $5 \mathrm{t}$ on a dry matter basis for the same period. Forage, particularly pasture, was the largest component of the Irish cow diet, typically accounting for $96 \%$ of the diet on a fresh matter basis and $82 \%$ of dry matter intake over the 3 yr. Within the cows' forage diet, grazed pasture was the dominant component and on average contributed 74 to $77 \%$ to the average annual cow fresh matter diet over the period. The proportion of pasture in the annual cow diet as fed was also identified as a good indicator of the time cows spend grazing (e.g., coefficient of determination $=0.85$ ). Monthly, forage was typically the main component of the cow diet, but the average contribution of concentrate was substantial

Received July 31, 2017.

Accepted January 26, 2018.

${ }^{1}$ Corresponding author: donal.mobrien@teagasc.ie for the early spring months of January and February (30 to $35 \%$ of dry matter intake). Grazed pasture was the dominant source of forage from March to October and usually contributed 95 to $97 \%$ of the diet as fed in the summer period. Overall, the national farm survey from 2013 to 2015 shows that Irish dairy farms are very reliant on forage, particularly pasture, regardless of whether it is reported on a dry matter basis or as fed. There is potential to replicate this methodology in any regions or nations where representative farm surveys are conducted.

Key words: milk, dairy, pasture, grass, cows

\section{INTRODUCTION}

Grass from grazing land (pasture) is an important source of feed for dairy cows in many parts of the world. When managed correctly, pasture is a very nutritious feed, which allows dairy cows to produce milk rich in protein, n-3, vitamins, and minerals. Consumers usually consider pastoral farming as healthy, animal friendly, and an environmentally sustainable method of milk production (Heerwagen et al., 2013; Elgersma, 2015). The rising consumer interest in how foods such as milk are produced has led to the development of milk brands that only allow farmers feed their cows grass [e.g., Organic Valley's Grassmilk (Wall Street Journal, 2014)]. These dairy products are in high demand in some nations and are sold at a market premium price in several supermarkets and convenience stores (Wall Street Journal, 2014; Organic Milk Suppliers Cooperative, 2015).

Consumers' intuition regarding pasture-based farming is not necessarily based on scientific research, but several research studies support their opinion. For instance, regarding animal welfare, research by Olmos et al. (2009), comparing cubicle-housed and pasturebased dairy cows over a full production cycle, showed that a pasture system improved cow welfare in terms of lameness. With regard to human health, a review of research studies by Elgersma (2015) highlighted that milk produced from grazing cows has a higher levels of desirable or healthy PUFA (e.g., $\alpha$-linolenic acid) than 
milk from housed cows fed TMR diets. Research studies by Rotz et al. (2009) and O'Brien et al. (2012) have highlighted how pasture can improve the environmental performance of primary dairy production by reducing greenhouse gas and ammonia emissions. However, some studies suggest grazing pasture has undesirable effects too. For instance, Mu et al. (2016) reported that pasture-based dairy farms had substantially greater nitrogen loss than dairy systems more reliant on grain or concentrate, which may have implications for water quality.

In recent decades, growth in dairy consumption has typically led to farms in most developed nations becoming larger and more intensive (Alvarez and del Corral, 2010; Winsten et al., 2010). Normally, as farms intensify, cows have less or no access to pasture and are instead housed, where they are typically fed ensiled forages and grains. Under these conditions, dairy farmers can carefully control the animal diet to produce more milk per cow than is possible by simply feeding pasture. This allows producers to generate more milk revenue and is often the main reason to move away from pastoral farming. However, this conflicts in some markets with consumer requirements for pasture feeding of cows. As a result, in certain nations, such as the Netherlands, some processors offer greater payments to milk suppliers when cows get access to grass for a minimum period (Elgersma, 2015). This satisfies current market requirements, but provides very little quantitative information on the amount of a cow's diet that comes from pasture and may not actually be advantageous from an environmental or animal welfare perspective.

The sustained market interest in grass-based dairy products is leading to greater consumer requests on the typical quantities of grazed pasture and forage (i.e., grazed pasture and conserved forages) in a dairy cow's diet. The primary goal of our study was to develop a methodology that can address this question by quantifying regularly the annual and monthly amounts of pasture and forage in the diet of dairy cows at a regional or national level. The quantification method was applied in a nation (Ireland) where farmers allow dairy cows to graze grass for most of the year (i.e., 8 to $10 \mathrm{mo}$ ). The method was operated using the country's representative farm survey, because this source facilitates regular national estimates of the typical amount of grazed pasture in a dairy cow's diet. Cow forage and pasture intakes were estimated as fed [fresh matter $(\mathbf{F M})]$ and in terms of DM primarily to assess the suitability of the fraction of grazed pasture in the cows' fresh or dry diet as an indicator of grazing season length. Another reason for estimating the dairy cow diet as fed was to highlight to consumers the typical fresh quantities of pasture consumed by grazing cows. The development of this pasture quantification methodology is expected to provide consumers with better information on the contribution of pasture to a cow's diet relative to the current market approach of communicating the minimum period cows have access to pasture.

\section{MATERIALS AND METHODS}

\section{Irish National Farm Survey}

To quantify pasture and forage consumed on commercial dairy farms we used data collected as part of the Irish national farm survey (NFS) from 2013 to 2015 (Hanrahan et al., 2014; Hennessy and Moran, 2015, 2016). The survey primarily collects economic information on costs and revenue, but it does provide additional technical information to estimate animal diets. For instance, O'Brien et al. (2015) previously used the NFS to quantify the carbon footprint of Irish milk. The NFS was established in 1972 and is part of the European Union's Farm Accountancy Data Network (FADN). The survey is carried out on a random representative sample of between 900 to 1,200 farms, depending on the total farm population of a given year. The national farm population is recorded annually by the Central Statistics Office (CSO). For ease of operation, several farmers stay in the NFS for many years, but after a certain period, farms exit and new farms are introduced to keep the sample representative. All farms in the NFS are weighted according to their area using annual aggregation factors from the national census so that the survey is representative of the national population.

The NFS categorizes farms into 6 different farming systems, namely dairy, tillage, sheep, cattle rearing, cattle other, and mixed livestock. Farms are classified as dairy producers when at least $66 \%$ of the standardized gross output of the farm comes from dairy production. For the 3 yr analyzed, 275 to 318 dairy farms were surveyed. This sample size was equivalent to about $2 \%$ of the total population of specialist Irish dairy producers. For the period, the national population was typically 16,000 farms. Trained auditors surveyed all farms 3 to 4 times per year. The auditors collected farm financial information, infrastructure data, and farm production information and data on the demographic profile of the farm households. The survey was also expanded to collect technical data on the length of the grazing season, monthly concentrate feeding, type of forage(s) conserved, milk production, and milk composition (Table 1). A half-day training course was provided to auditors on collecting this technical data.

Generally, farmers that participated in the NFS had detailed farm accounts and diaries. Thus, the additional 
Table 1. Number and mean characteristics of specialized Irish dairy farms weighted to represent national population

\begin{tabular}{lccc}
\hline Item & 2013 & 2014 & 2015 \\
\hline No. of farms & 275 & 318 & 314 \\
Dairy farm area, ha & 34.1 & 34.0 & 35.3 \\
No. of cows & 68 & 68 & 70 \\
Cows culled, $\%$ & 17 & 18 & 14 \\
Stocking rate, cows/ha & 1.98 & 1.99 & 1.97 \\
Milk solids yield, ${ }^{1} \mathrm{~kg} /$ cow & 403 & 305 & 4.02 \\
Fat, \% & 3.95 & 3.98 & 3.48 \\
Protein, $\%$ & 3.38 & 947 & 934 \\
Concentrate as fed, kg/cow & 1,172 & Mar. 4,2014 & Mar. 3, 2015 \\
Turnout date to pasture & Mar. 7,2013 & Nov. 17,2014 & Nov. 13,2015 \\
Full-time housing date & Nov. 18,2013 & 258 & 255 \\
Access to pasture, d & 256 & &
\end{tabular}

${ }^{1}$ Milk solids yield = annual yield of milk fat and protein.

NFS data requested was normally readily available and collected in 2 to $3 \mathrm{~h}$. Farms were excluded from the survey if the data provided was inadequate or unreliable. Farms were also omitted from the evaluation if they had or began to cease supplying milk during the period of the study. Information necessary to compute the diet of animals (e.g., BW change) that could not be collected from surveys (Table 2) was obtained from national publications (O'Mara, 2006; Archbold et al., 2012).

\section{Computing the Dairy Cow Diet}

Over $95 \%$ of dairy farms included in the NFS operated spring-calving grazing systems. The remaining dairy farms included in the NFS also supplied milk throughout the winter to satisfy the fresh milk market, which represents less than $10 \%$ of the nation's milk pool (CSO, 2017). Generally, farmers aimed to maximize profitability by optimizing milk output from grazed pasture (Kennedy et al., 2005). Calving was usually synchronized with the onset of grass growth in early or mid-spring. Generally, calved cows remained on pasture until late autumn or early winter. Pasture was usually offered to cows through a rotational grazing system, where cows were offered sections or paddocks of pasture for 1 to $2 \mathrm{~d}$ or until a specific grazing height was reached (e.g., 4 to $5 \mathrm{~cm}$ ) and then moved to a new paddock. In late spring or summer, when grass growth exceeded feed demand, surplus grass was harvested as grass silage, hay, or both and fed to cows indoors from early winter to early spring. Cows were offered

Table 2. Feedstuffs DM and energy values, and cow average BW and energy requirement for annual body weight change (BWC) estimated in the present study

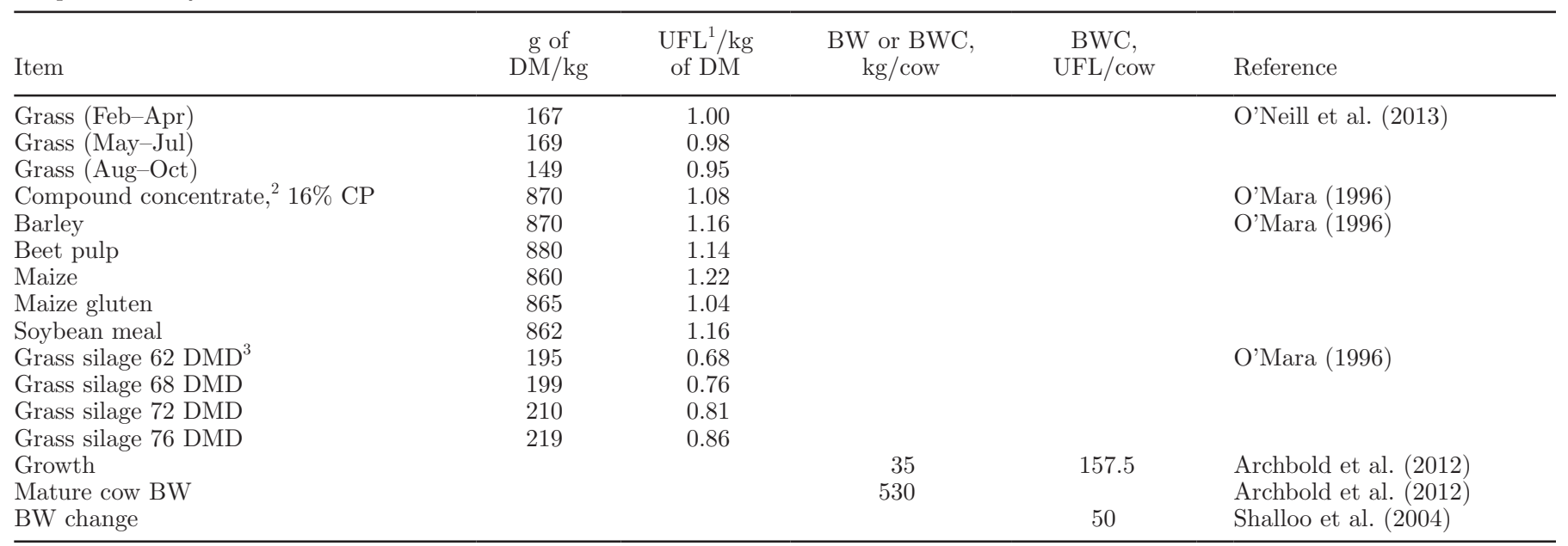

${ }^{1} \mathrm{UFL}$ (unité fourragère lait) = feed unit for lactation where $1 \mathrm{UFL}$ equals $7.11 \mathrm{MJ}$ of net energy.

${ }^{2}$ Concentrate ingredients as fed were beet pulp (35\%), maize gluten (26\%), barley (25\%), soybean meal (11\%), and a mineral and vitamin mix (3\%).

${ }^{3} \mathrm{DMD}=$ dry matter digestibility. 
purchased concentrate feeds when grass growth was insufficient to meet herd feed requirements, and when animal intake potential was insufficient to meet animal requirements post calving.

Monthly forage intakes by cows were estimated by first calculating the total net energy (NE) requirements for milk production, maintenance, activity, growth, pregnancy, and BW change (Jarrige, 1989; O'Mara, 1996). Subsequently, monthly data collected on concentrate feedstuffs were multiplied by typical concentrate NE values from O'Mara (1996) to estimate NE provided by concentrate feeds. The NE from concentrate was subtracted from the cows' total NE requirement to estimate the NE provided by forage per month. Similar to Flysjö et al. (2011) the proportion of NE that came from pasture was estimated by relating the period cows spent outdoors to the NE provided by forage monthly. Net energy provided by conserved forage was estimated monthly as the difference between NE provided from forage and grazed pasture, because most farms surveyed did not regularly record the quantity of conserved forage fed to cows.

A series of livestock NE requirement equations from O'Mara (1996) were used to estimate the NE requirements of cows. The feed unit for lactation (unité fourragère lait, UFL) is the basic unit for these NE requirement equations, where 1 UFL equals 7.11 MJ of NE (Jarrige, 1989). The calculations included a NE allowance for BW change and typical growth between lactations for all cows in the herd. The equations used to calculate a cow's NE requirements for maintenance and activity, milk production, pregnancy, BW change, and growth were as follows:

$$
\begin{aligned}
& \text { Maintenance and activity }= \\
& \left\{\left[\begin{array}{l}
\left.1.4+0.6 \times\left(\frac{\mathrm{BW}}{100}\right)\right] \times\left(\frac{\mathrm{GSL}}{365}\right) \times(1+\mathrm{AAG}) \\
+\left[1.4+0.6 \times\left(\frac{\mathrm{BW}}{100}\right)\right] \times\left(\left[1-\left(\frac{\mathrm{GSL}}{365}\right)\right] \times(1+\mathrm{AAH})\right)
\end{array}\right\}\right. \\
& \times 365 \times \text { no. of cows, }
\end{aligned}
$$

where BW represents the cow BW, GSL represents grazing season length, AAG represents a $20 \%$ activity increase for grazing activity, and AAH represents a $10 \%$ increase for indoor cow activity.

Milk production $=$

$\left[\begin{array}{l}(0.054 \times \text { Fat } \%)+(0.031 \times \operatorname{Prot} \%) \\ +(0.028 \times \text { Lact } \%)-0.015\end{array}\right] \times($ total milk produced $)$,
Pregnancy $($ cows $)=153$ UFL $\times$ no. of cows $\times 0.85, \quad[3]$

where Prot is protein, Lact is lactose, and 0.85 is the assumed proportion of cows pregnant (Buckley et al., 2007).

Pregnancy $($ heifers $)=153$ UFL $\times$ no. of heifers $\times 0.95$,

where 0.95 is the assumed proportion of heifers pregnant (Archbold et al., 2012).

Body weight change $=$ no. of cows $\times 50$ UFL $/$ cow, $[5]$

Growth $=$ no. of cows $\times 35 \mathrm{~kg}$ of $\mathrm{LWG}$

$\times 4.5 \mathrm{UFL} / \mathrm{kg}$ of LWG,

where LWG is annual live weight gain that was assumed to occur for all cows.

For the analysis, forage, and feedstuff UFL values, cow BW and $\mathrm{NE}$ required for cow BW changes were estimated based on previous research and industry consultation as outlined in Table 2. These estimates were taken as averages across all farms and years.

\section{Scenarios Investigated}

Dry Matter. Dry matter intakes of pasture and conserved forage were computed by dividing the $\mathrm{NE}$ provided by a forage by its $\mathrm{NE}$ value per kilogram of DM. O'Mara (1996) provided the DM contents of forages and concentrate, and was used to estimate the NE values of forages per kilogram of DM (Table 2).

Fresh Matter-As Fed. Fresh matter intakes of pasture and conserved forage were computed by dividing the NE provided by a forage by its $\mathrm{NE}$ value per kilogram of FM. The NE values of forages on a DM basis were converted to NE values per kilogram of FM using forage DM contents reported by O'Mara (1996).

\section{Correlation and Regression Analyses}

The length of the grazing season and the proportion of pasture in a dairy cow's annual as-fed or DM diet were related using the correlation and regression analyses procedures of the SAS software package (version 9.1.3, SAS Institute Inc., Cary, NC). The strength of relationships between these measures was compared for the different approaches used to estimate cow pasture intake. The analyses were carried out for all years. 


\section{Sensitivity Analysis}

The sensitivity of dairy cow's pasture and total feed intake to key factors obtained from reports and industry was evaluated by increasing or decreasing an assumed factor by 3 to $5 \%$ compared with the original estimate. The effect of altering a multitude of these factors simultaneously was not assessed. The analysis was carried out for all specialist dairy farms part of the NFS in 2015. The cow factors analyzed were average BW and growth (average annual live weight gain). The forage factors examined were pasture DM content, pasture NE value, and conserved forages $\mathrm{NE}$ values. Conserved forages included grass silage and alternative forages. The latter mainly consisted of maize silage, whole crop cereal silage, and fodder beet. This group of forages and grass silage was treated as a single factor (conserved forage) for this analysis.

\section{RESULTS}

\section{Annual Irish Cow Diet}

Annual total intake as fed per dairy cow averaged $22.7 \mathrm{t}$ in 2013, $23.7 \mathrm{t}$ in 2014, and $24.8 \mathrm{t}$ in 2015 (Table $3)$. Forage accounted for the majority of Irish cows' annual diet for all years averaging 94.8 to $96.2 \%$ of the diet on a FM basis. Pasture was the largest individual component of dairy cow diets and on average contributed 74 to $77 \%$ of the average annual cow FM diet over the period. The high contribution of pasture to the annual cow diet was primarily explained by the long grazing season, which averaged 255 to 258 d over the 3 -yr period. Grass silage was the second largest fresh component of the annual diet (18 to $19.2 \%$ ) followed by concentrate feed (3.8 to $5.2 \%$ ) for the period.

In terms of DM, cows' annual total intake was lower than on a FM basis averaging 4.8 to 5.0 t over the 3 yr (Table 3). Again, forage was the largest feed source representing 78.9 to $83.7 \%$ of the average cow annual DM diet. Similar to estimating the annual cow diet on a FM basis, grazed pasture was the main component of the diet on a DM basis, accounting for 56.8 to $62.2 \%$ of the average cow diet. Concentrate was the second largest individual feed component of the annual cow diet on a DM basis in 2013, but for 2014 and 2015, grass silage represented a greater share of the annual diet (Table 4).

\section{Monthly Irish Cow Diet}

Averaged over the 3 yr, cow total monthly FM intake usually increased with milk yield (Figure 1). Monthly cow milk yield normally increased from $3.9 \mathrm{~L} /$ per cow per day in January to peak at $23.0 \mathrm{~L} /$ per cow per day in June. Over this period, monthly total FM intake typically increased from $33.7 \mathrm{~kg}$ in January to $84.3 \mathrm{~kg}$ of FM/cow per day in June. From June onward, cow monthly milk yield declined, but monthly cow total FM intake increased in September after declining in July and August due to an estimated decrease in pasture quality and NE per kilogram of DM, and an increase in moisture content in autumn. Cow total FM intake declined from September onward as milk yield fell. On a DM basis, the trend in cow total intake, averaged over the 3 yr, was similar to the FM analysis (Figure 2). Cow total DMI peaked in June at $15.9 \mathrm{~kg}$ of DM/ cow per day and declined to $13.8 \mathrm{~kg}$ of $\mathrm{DM} /$ cow per day in August. A slight increase of $0.3 \mathrm{~kg}$ of DM/cow per day in total DMI occurred in September, because pasture quality and NE per kilogram of pasture DM were estimated to decline. Cow total DMI decreased in October and continued to decline to $10.2 \mathrm{~kg}$ of DM/cow per day in January.

Forage was typically the main component of a cow's monthly FM diet (Figure 3). Grass silage was the dominant contributor to a cow's FM diet from December until February (71 to 87\%) and was the main FM diet

Table 3. Typical as-fed cow diets (mean $\pm \mathrm{SD}$ ) of specialist dairy farms from the Irish national farm survey

\begin{tabular}{|c|c|c|c|c|}
\hline Item & 2013 & 2014 & 2015 & $\begin{array}{c}\text { Average } \\
2013-2015\end{array}$ \\
\hline No. of farms & 275 & 318 & 314 & $302\left(907^{1}\right)$ \\
\hline Total intake, t of fresh matter $(\mathrm{FM}) / \mathrm{cow}$ & $22.7 \pm 2.2$ & $23.7 \pm 2.3$ & $24.8 \pm 2.5$ & $23.7 \pm 2.4$ \\
\hline Pasture, $\%$ of FM & $74.2 \pm 8.0$ & $76.8 \pm 6.9$ & $76.9 \pm 7.8$ & $76.0 \pm 8.0$ \\
\hline Grass silage, $\%$ of FM & $19.2 \pm 7.6$ & $18.0 \pm 6.0$ & $18.4 \pm 7.1$ & $18.6 \pm 7.3$ \\
\hline Grass, $^{2} \%$ of FM & $93.4 \pm 3.6$ & $94.9 \pm 3.4$ & $95.3 \pm 3.0$ & $94.5 \pm 3.3$ \\
\hline Alternative forages, ${ }^{3} \%$ of FM & $1.5 \pm 2.2$ & $1.1 \pm 2.0$ & $0.9 \pm 1.9$ & $1.2 \pm 2.3$ \\
\hline Forage, ${ }^{4} \%$ of FM & $94.8 \pm 2.3$ & $96.0 \pm 2.1$ & $96.2 \pm 2.0$ & $95.7 \pm 2.2$ \\
\hline Concentrate, $\%$ of FM & $5.2 \pm 2.3$ & $4.0 \pm 2.1$ & $3.8 \pm 2.0$ & $4.3 \pm 2.2$ \\
\hline
\end{tabular}

\footnotetext{
${ }^{1}$ Total farm years.

${ }^{2}$ Grass consisted of pasture and grass silage. Pasture is grass grazed by cows outdoors.

${ }^{3}$ Alternative forage mainly consisted of whole crop cereal silages, maize silage, and fodder beet.

${ }^{4}$ Forage consisted of pasture, grass silage, and any alternative forages.
} 
Table 4. Typical DM cow diets (mean \pm SD) of specialist dairy farms from the Irish national farm survey

\begin{tabular}{lcccc}
\hline Item & & & & Average \\
& 2013 & 2014 & 2015 & $2013-2015$ \\
\hline No. of farms & 275 & 318 & 314 & $302\left(907^{1}\right)$ \\
Total intake, t of DM/cow & $4.8 \pm 0.5$ & $4.8 \pm 0.4$ & $5.0 \pm 0.4$ & $4.8 \pm 0.5$ \\
Pasture, \% of DM & $56.8 \pm 10.4$ & $61.6 \pm 9.4$ & $62.2 \pm 9.9$ & $60.2 \pm 10.1$ \\
Grass silage, \% of DM & $19.8 \pm 7.2$ & $19.5 \pm 6.0$ & $20.1 \pm 6.8$ & $19.8 \pm 7.0$ \\
Grass, ${ }^{2} \%$ of DM & $76.6 \pm 8.3$ & $81.0 \pm 8.2$ & $82.3 \pm 7.6$ & $80.0 \pm 8.3$ \\
Alternative forages, ${ }^{3} \%$ of DM & $2.3 \pm 3.5$ & $1.8 \pm 3.0$ & $1.4 \pm 2.5$ & $1.8 \pm 3.0$ \\
Forage, \% of DM & $78.9 \pm 7.1$ & $82.8 \pm 7.2$ & $83.7 \pm 6.9$ & $81.8 \pm 7.3$ \\
Concentrate, \% of DM & $21.1 \pm 7.1$ & $17.2 \pm 7.2$ & $16.3 \pm 6.9$ & $18.2 \pm 7.3$ \\
\hline
\end{tabular}

${ }^{1}$ Total farm years.

${ }^{2}$ Grass consisted of pasture and grass silage. Pasture is grass grazed by cows outdoors.

${ }^{3}$ Alternative forage mainly consisted of whole crop cereal silages, maize silage, and fodder beet.

${ }^{4}$ Forage consisted of pasture, grass silage, and any alternative forages.

component in November (54\%). This corresponds to the winter period when little milk is produced on Irish farms (8.6\%, CSO, 2017). From March onward, grazed pasture was the largest component of the diet as fed, accounting for $97 \%$ of a cows feed from May to August. Concentrate accounted for 8 to $12 \%$ of a cow's FM diet from January to March, but contributed less than $5 \%$ for the remaining months.

On a DM basis, forage was the main feed cows consumed monthly, but the contribution was lower than on a FM basis (Figure 4). The contribution of concentrate to the cow DM diet was substantial from January to April (21 to 35\%) and over 10\% of the diet for the remaining months. Grass silage was the largest component of a cow's DM diet from November to February (53 to $75 \%$ ). From May to October, cows largely consumed grazed pasture. Typically, grazed pasture accounted for 76 to $87 \%$ of the cows' DM diet during this period. Pasture was also the main component of the diet in mid to late spring, accounting for 41 to $71 \%$ of the cow diet in March and April.

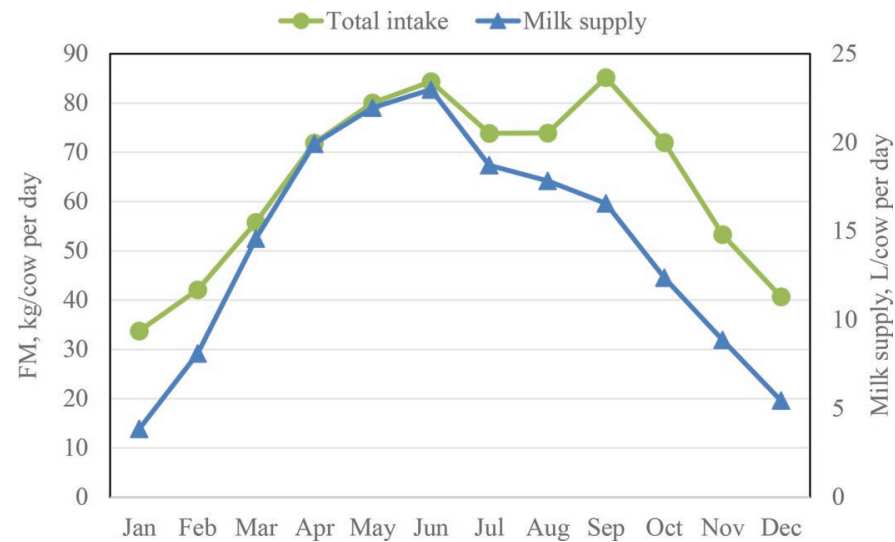

Figure 1. Mean monthly fresh matter (FM) intakes and milk supply of an average Irish dairy cow estimated from the national farm survey from 2013 to 2015. Color version available online.

\section{Grazing Season and Pasture Diet}

The positive correlation between the length of the grazing season and the proportion of pasture in a typical cow's as-fed annual diet ranged from $\mathrm{r}=0.86$ in 2014 to $\mathrm{r}=0.92$ in $2013(P<0.001)$. On a DM basis, the strength of the correlation between these measures was lower than the as fed. The DM associations ranged from $\mathrm{r}=0.79$ in 2014 to $\mathrm{r}=0.84$ in $2013(P<0.001)$. For each year assessed, there was a linear relationship between the length of the grazing season and the proportion of pasture in the cow diet. Furthermore, estimating cow intake as fed instead of on a DM basis improved the goodness of fit $\left(\mathrm{R}^{2}\right)$ across years (e.g., the 2013 as fed $R^{2}$ was 0.85 compared with an $R^{2}$ of 0.71 for the DM approach).

\section{Cow Diets and Assumed Factors}

As fed and on a DM basis, dairy cows' average annual pasture and total intakes in 2015 were generally robust to changes in key assumed factors (Table 5).

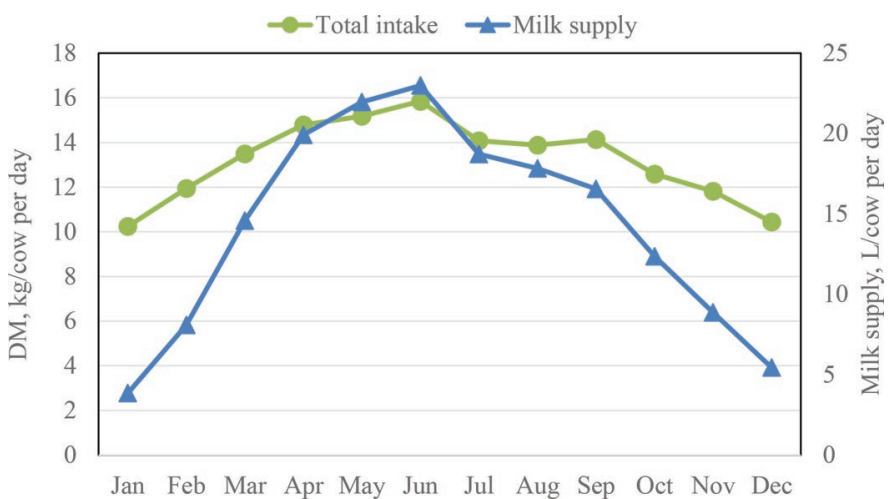

Figure 2. Mean monthly DMI and milk supply of an average Irish dairy cow estimated from the national farm survey from 2013 to 2015. Color version available online. 


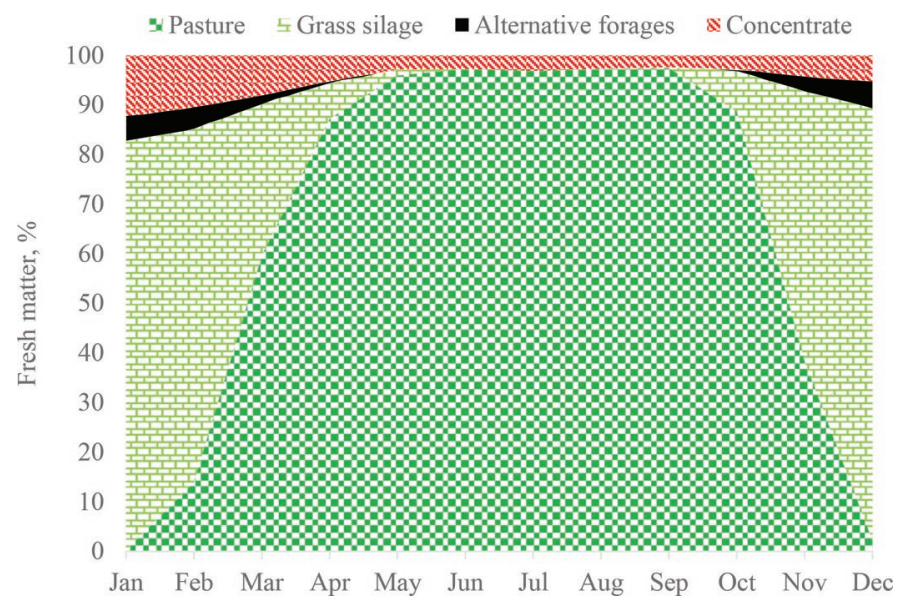

Figure 3. Typical monthly as-fed feed budget of an average Irish dairy cow estimated from the national farm survey from 2013 to 2015 . Pasture is grass grazed by cows outdoors. Alternative forage mainly consisted of whole crop cereal silages, maize silage, and fodder beet. Color version available online.

Varying the DM content of pasture by $5 \%$ brought about the largest reduction $(-5 \%)$ and increase $(+6 \%)$ in an average cow's annual total intake as fed. As expected, this factor had a greater influence on the pasture component of the fresh diet. Pasture quality and cow BW were the only other assumed factors that had an influence on the average Irish cow's as-fed diet $( \pm 2$ to $3 \%)$. For the average cow, annual pasture and total DMI pasture quality had the greatest effect ( \pm 2 to $3 \%$ ). Cow BW had a similar effect as pasture DM content ( \pm 1 to $2 \%)$ on cows' annual total DMI. The latter factor changed cows' annual DMI, because pasture DM content indirectly influenced the $\mathrm{NE}$ value of pasture.

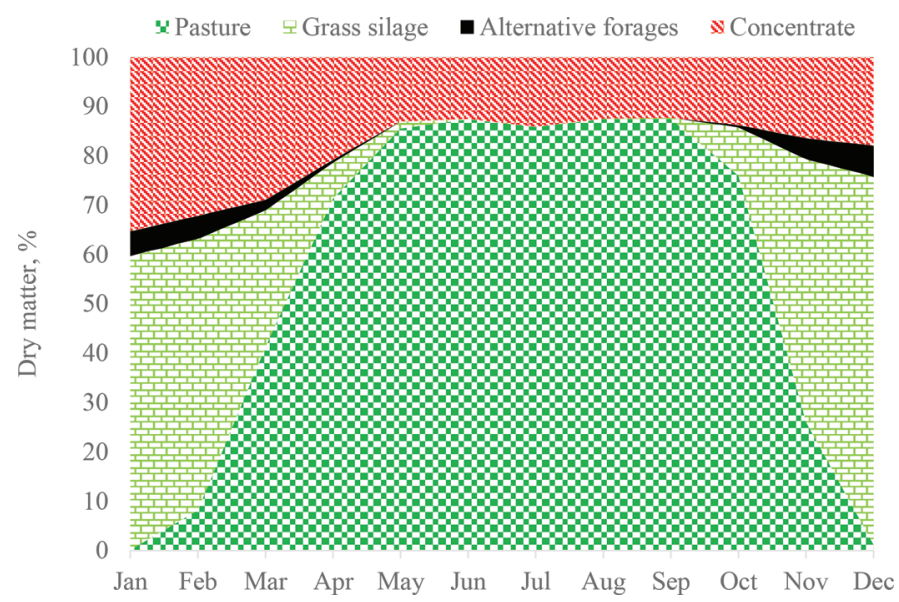

Figure 4. Typical monthly DM feed budget of an average Irish dairy cow estimated from the national farm survey from 2013 to 2015. Pasture is grass grazed by cows outdoors. Alternative forage mainly consisted of whole crop cereal silages, maize silage, and fodder beet. Color version available online.
The remaining assumed factors only had negligible effects on cow diets $(< \pm 1 \%)$.

\section{DISCUSSION}

To our knowledge, this research is one of the first studies to estimate the total diet of grazing dairy cows on a countrywide scale. It builds on previous research by Läpple et al. (2012) examining the different factors that influence the length of the grazing season on Irish dairy farms. However, comparing our estimates of the quantity or proportion of pasture in the diet of dairy cows to previous work is difficult given that most published estimates are from research farms. Typically, research dairy farms are not operating under commercial conditions and are usually testing the effect different treatments have on animal health or performance variables under controlled experimental conditions. Therefore, comparisons between research and commercial farms are likely to be biased. Nevertheless, despite this shortcoming, comparing our results with similar farms, even noncommercial farms, does show whether they lay within the previous range of estimates. This approach gives an indication of the validity of cow feed intake estimates and the usefulness of the method developed to assess the diet of grazing dairy cows.

We compared our results to the studies of Macdonald et al. (2001), Vance et al. (2012), and Patton et al. (2016), where cows normally had access to pasture for the late spring, summer, and autumn months, and were largely fed grass silage over the winter period. Vance et al. (2012) evaluated UK grazing systems where 750 $\mathrm{kg}$ of concentrate DM was offered per cow per year. In addition, the study compared this type of system to a total confinement system where 2.9 t of concentrate DM was offered per cow per annum. As anticipated, the results showed the average milk yield/lactation of the confinement system was (35\%) higher than the grazing system. Similarly, the annual cow DMI was greater for the confinement system (5.8 t per cow) than the grazing system (4.7 t per cow). However, as fed, average annual cow intake was $23 \mathrm{t}$ for the grazing system and $16 \mathrm{t}$ for the confinement system. The lower annual cow FM intake in the confinement system was due to the high usage of concentrate feed (3.3 t of FM/cow) that had a very low moisture content (120 to $130 \mathrm{~g} / \mathrm{kg}$ ) compared with forage (780 to $850 \mathrm{~g} / \mathrm{kg}$ ).

Patton et al. (2016) compared milk production per cow and per hectare, and the amount of concentrate required for 2 Irish pasture-based systems differing in stocking rate on the grazing platform (3.1 and 4.5 cows/ ha). Cows within this study typically grazed pasture for $275 \mathrm{~d}$ per annum and were fed $551 \mathrm{~kg}$ of concentrate $\mathrm{DM} /$ cow per year when stocked at 3.1 cows/ha on the 


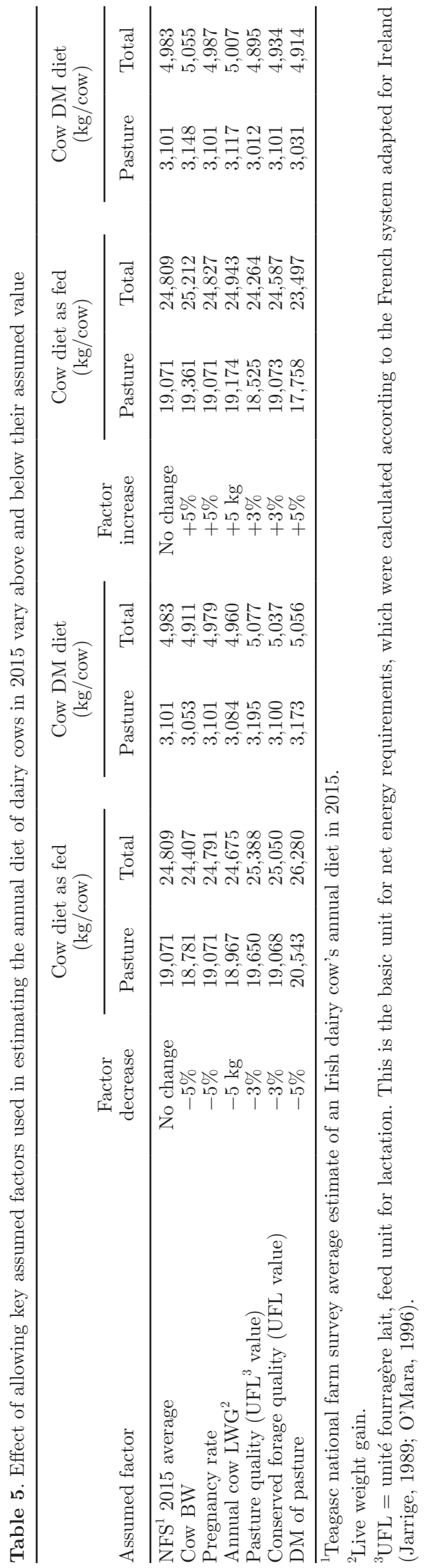

grazing platform. The estimated annual quantity of forage DM consumed at this stocking rate was $3.9 \mathrm{t}$ per cow or $21.8 \mathrm{t}$ in terms of FM. Forage intake primarily consisted of pasture, which accounted for $61 \%$ of the total DM diet or $71 \%$ on a fresh basis. Increasing the stocking rate to 4.5 cows/ha on the grazing platform in the study of Patton et al. (2016) increased the requirement for concentrate DM to $872 \mathrm{~kg}$ per cow per year. This reduced the requirement for forage to $3.4 \mathrm{t}$ of $\mathrm{DM}$ per cow (19.1 t of FM) and the proportion of pasture in a cow's total diet on a DM basis to 47 or $60 \%$ on a fresh basis.

The study of Macdonald et al. (2001) was carried out in New Zealand and examined the effect of 5 different stocking rates over 2 lactations on several dairy farm performance variables, farm profitability, and pasture production. The goal of Macdonald et al. (2001) was to quantify the change in efficiency of feed utilization and milk production when annual DMI per cow was altered through stocking rate. To simplify the comparison of results, we averaged annual cow DMI across the 5 herds over the $2 \mathrm{yr}$, similar to Beukes et al. (2008). This resulted in average annual DMI of $5.1 \mathrm{t}$ per cow with pasture accounting for approximately $4.8 \mathrm{t}$ of $\mathrm{DM}$ per cow.

Comparing our estimates of annual cow DMI to these studies shows that our forage intakes were within the range of previous estimates for pasture-based systems. Our estimates for total forage intake for grazing systems were very similar to Macdonald et al. (2001) and Vance et al. (2012), but greater than Patton et al. (2016). However, the milk solids yield per cow of the farm system evaluated by Patton et al. (2016) was lower than our average and that of Macdonald et al. (2001). Milk solids yield is an important factor in driving cow intake and partly explained the different forage estimates. Further variables that also potentially explained the difference between our estimates and those of Patton et al. (2016) include differences in BW, concentrate supplementation, and chemical composition of forage.

The annual proportion of pasture in the diet of herds investigated by Macdonald et al. (2001) was greater than our study and that of Patton et al. (2016). This was mainly due to the longer grazing period $(300 \mathrm{~d}$ or more) and lower average level of concentrate supplementation in the New Zealand study at that time. However, this study was carried out on a research farm from 1998 to 2000 and is unlikely to be representative of the annual cow diet of the current New Zealand industry. On a monthly basis, the proportion of pasture in the total cow diet for the summer months was over $95 \%$ on a DM basis for the systems considered by Patton et al. (2016). This was also the case for $10 \%$ of the farms assessed in the NFS. Therefore, for the key summer 
period, when most milk is produced from a seasonal calving dairy farm, a large proportion of the diet originates from grazed pasture.

Overall, the comparison with previous research systems provides solid validation that Irish dairy farms are highly reliant on grass, particularly pasture, for a large proportion of their diet. There is potential to increase further the proportion of pasture in the diet of Irish dairy farms by reducing concentrate supplementation and increasing grass growth and utilization evident on the top $10 \%$ of farms from the NFS (O'Brien et al., 2015). Several studies have provided recommendations on how this can be achieved at a farm level (e.g., Sayers and Mayne, 2001; O'Donnell et al., 2008; O'Donovan et al., 2011; Hanrahan et al., 2017). Examples include increasing grassland reseeding rates, measuring pasture covers, and setting targets for pre- and postgrazing heights throughout the grazing season. The adoption of such recommendations will deliver consumer demands in terms of pasture fed cows and was reported by Dillon et al. (2005) to improve the long-term viability of pasture-based dairy farms.

The European Union FADN already evaluates dairy farm viability and based on this work could be expanded to estimate the typical annual diet of dairy cows on a countrywide scale across Europe. Since 2012, the Irish part of the FADN (the NFS) has adopted the additional survey we created to estimate typical Irish cow diets, annually or monthly. Additionally, the nation has also recently integrated the survey into its dairy quality assurance scheme that began operations in 2013 (Bord Bia, 2013). Based on our experience, it should be possible to repeat our approach to estimating typical cow diets for other European nations that are part of the FADN. However, farm records required to estimate forage intakes may be difficult to gather for some member nations. Outside of Europe, this approach can be applied where good quality farm information and local research data are readily available. Research or industry farm information (e.g., pasture NE value) should be reviewed and updated regularly. Ideally, more information should be collected from farms to reduce the error associated with such assumptions. This may be possible going forward for some of the key assumed factors we highlighted using precision farming technologies [e.g., cow BW could be captured from imagery technology on farms (Kuzuhara et al., 2015)].

The outputs from the methodology we have developed can inform interested consumers further on the providence of the food they consume. This has become an important question in several developed nations and one which dairy processors and retailors wish to provide reliable information to their customers. The proportion of grass in the diet of dairy cows is becom- ing of particular interest and is potentially seen as an indicator of the period cows spend outdoors grazing. The latter is already an important measure for specific dairy products in some regions, which some consumers are willing to pay a premium for. Further information can be provided on grazing cow diets and grazing season length as we have demonstrated. Our national approach to estimating a cow's diet has the potential to be replicated for more countries around the world. This would benefit the global consumer by allowing them to make more informed decisions about the type of dairy products they wish to purchase in the future. Over the long term, it may also increase the overall value of dairy products for milk suppliers and processors.

\section{CONCLUSIONS}

This study expanded a nationally representative survey to quantify the average intake of pasture by Irish dairy cows on a monthly and annual basis. Our results demonstrated that forage, particularly grazed pasture, was the largest component of an Irish cow's diet and typically accounted for over $95 \%$ of a cow's annual diet as fed over the $3 \mathrm{yr}$ evaluated. Grazed pasture was the main source of forage and represented $76 \%$ of an Irish cow's annual FM diet over the period. From March to October, pasture was the dominant source of forage and normally contributed over $95 \%$ of a cow's FM diet in the summer period (May to July). The approach we developed to estimate the grazing cow diet of dairy farms can be applied in other regions or nations where similar farm surveys are routinely carried out, such as the European Union FADN (European Commission, 2013). This would provide European Union and nonEuropean Union consumers interested in the origin of their food with an estimate of the typical amount of pasture used in the production of a region's or country's dairy product(s).

\section{ACKNOWLEDGMENTS}

The authors express their gratitude to the farmers that participated in the national farm survey. We are grateful to the staff of the national farm survey who carried out the recording, collection, and validation of the database. We also thank the anonymous reviewers for their helpful insights and contributions.

\section{REFERENCES}

Alvarez, A., and J. del Corral. 2010. Identifying different technologies using a latent class model: Extensive versus intensive dairy farms. Eur. Rev. Agric. Econ. 37:231-250.

Archbold, H., L. Shalloo, E. Kennedy, K. M. Pierce, and F. Buckley. 2012. Influence of age, body weight and body condition score be- 
fore mating start date on the pubertal rate of maiden HolsteinFriesian heifers and implications for subsequent cow performance and profitability. Animal 6:1143-1151.

Beukes, P. C., C. C. Palliser, K. A. Macdonald, J. A. S. Lancaster, G. Levy, B. S. Thorrold, and M. E. Wastney. 2008. Evaluation of a whole-farm model for pasture-based dairy systems. J. Dairy Sci. 91:2353-2360.

Bord Bia. 2013. Sustainable dairy assurance scheme: Producer standard. Irish Food Board, Dublin 2, Ireland. Accessed Oct. 1, 2017. http://www.bordbia.ie/industry/farmers/quality/pages/ sustainabledairyassurancescheme.aspx.

Buckley, F., P. Dillon, and J. F. Mee. 2007. Major management factors associated with the variation in reproductive performance of Irish dairy herds. Final report. Project number 5070. Teagasc, Moorepark Dairy Production Research Centre, Cork, Ireland.

Central Statistics Office (CSO). 2017. Agriculture and fishing statistical products. Central Statistics Office, Skehard Road, Cork, Ireland. Accessed May 1, 2017. http://www.cso.ie/en/index.html.

Dillon, P., J. R. Roche, L. Shalloo, and B. Horan. 2005. Optimising financial returns from grazing in temperate pastures. Pages 131148 in Utilization of Grazed Grass in Temperate Animal Systems. Proceedings Satellite Workshop of the XXth Int. Grassl. Congr. Cork, Ireland. J. J. Murphy, ed. Wageningen Academic Publishers, the Netherlands.

Elgersma, A. 2015. Grazing increases the unsaturated fatty acid concentration of milk from grass-fed cows: A review of the contributing factors, challenges and future perspectives. Eur. J. Lipid Sci. Technol. 117:1345-1369

European Commission. 2013. Concept of farm accountancy data network. Accessed Mar. 30, 2017. http://ec.europa.eu/agriculture/ rica/concept_en.cfm.

Flysjö, A., M. Henriksson, C. Cederberg, S. Ledgard, and J.-E. Englund. 2011. The impact of various parameters on the carbon footprint of milk production in New Zealand and Sweden. Agric. Syst. 104:459-469.

Hanrahan, K., T. Hennessy, A. Kinsella, and B. Moran. 2014. Nationa farm survey 2013. Teagasc agricultural economics and farm surveys department. Athenry, Co. Galway.

Hanrahan, L., A. Geoghegan, M. O’Donovan, V. Griffith, E. Ruelle, M. Wallace, and L. Shalloo. 2017. PastureBase Ireland: A grassland decision support system and national database. Comput. Electron. Agric. 136:193-201.

Heerwagen, L., T. Christensen, and P. Sandøe. 2013. The prospect of market-driven improvements in animal welfare: Lessons from the case of grass milk in Denmark. Animals (Basel) 3:499.

Hennessy, T., and B. Moran. 2015. National farm survey 2014. Teagasc agricultural economics and farm surveys department. Athenry, Co. Galway, Ireland.

Hennessy, T., and B. Moran. 2016. National farm survey 2015. Teagasc agricultural economics and farm surveys department. Athenry, Co. Galway, Ireland.

Jarrige, R., ed. 1989. Ruminant Nutrition: Recommended allowances and feed tables. John Libbey Eurotext, Montrouge, France.

Kennedy, E., M. O'Donovan, J. P. Murphy, L. Delaby, and F. O'Mara. 2005. Effects of grass pasture and concentrate-based feeding systems for spring-calving dairy cows in early spring on performance during lactation. Grass Forage Sci. 60:310-318.

Kuzuhara, Y., K. Kawamura, R. Yoshitoshi, T. Tamaki, S. Sugai, M. Ikegami, Y. Kurokawa, T. Obitsu, M. Okita, T. Sugino, and T. Yasuda. 2015. A preliminarily study for predicting body weight and milk properties in lactating Holstein cows using a three-dimensional camera system. Comput. Electron. Agric. 111:186-193.

Läpple, D., T. Hennessy, and M. O'Donovan. 2012. Extended grazing: A detailed analysis of Irish dairy farms. J. Dairy Sci. 95:188-195.

Macdonald, K. A., J. W. Penno, P. K. Nicholas, J. A. Lile, M. Coulter, and J. A. S. Lancaster. 2001. Farm systems-Impact of stock- ing rate on dairy farm efficiency. Proceedings of the New Zealand Grassland Association 63:223-227.

Mu, W., C. E. van Middelaar, J. M. Bloemhof, J. Oenema, and I. J. M. de Boer. 2016. Nutrient balance at chain level: A valuable approach to benchmark nutrient losses of milk production systems. J. Clean. Prod. 112:2419-2428.

O'Brien, D., T. Hennessy, B. Moran, and L. Shalloo. 2015. Relating the carbon footprint of milk from Irish dairy farms to economic performance. J. Dairy Sci. 98:7394-7407.

O'Brien, D., L. Shalloo, J. Patton, F. Buckley, C. Grainger, and M. Wallace. 2012. A life cycle assessment of seasonal grass-based and confinement dairy farms. Agric. Syst. 107:33-46.

O'Donnell, S., L. Shalloo, A. M. Butler, and B. Horan. 2008. A survey analysis of opportunities and limitations of Irish dairy farmers. J. Farm Management 13:419-434.

O'Donovan, M., E. Lewis, and P. O'Kiely. 2011. Requirements of future grass-based ruminant production systems in Ireland. Ir. J Agric. Food Res. 50:1-21.

O'Mara, F. 1996. A net energy system for cattle and sheep. Department of Animal Science and Production, Faculty of Agriculture, University College Dublin, Belfield, Dublin, Ireland.

O'Mara, F. 2006. Development of emission factors for the Irish cattle herd. Environmental Protection Agency, Johnstown Castle, Co. Wexford, Ireland.

O'Neill, B. F., E. Lewis, M. O'Donovan, L. Shalloo, F. J. Mulligan, T. M. Boland, and R. Delagarde. 2013. Evaluation of the GrazeIn model of grass dry-matter intake and milk production prediction for dairy cows in temperate grass-based production systems. 1Sward characteristics and grazing management factors. Grass Forage Sci. 68:504-523.

Olmos, G., L. Boyle, A. Hanlon, J. Patton, J. J. Murphy, and J. F. Mee. 2009. Hoof disorders, locomotion ability and lying times of cubicle-housed compared to pasture-based dairy cows. Livest. Sci. 125:199-207.

Organic Milk Suppliers Cooperative. 2015. Organic milk market report 2015. Accessed May 3, 2017. http://www.omsco.co.uk/_clientfiles/ pdfs/MarketReport-2015.pdf.

Patton, D., K. M. Pierce, and B. Horan. 2016. Effect of stocking rate on milk and pasture productivity and supplementary feed use for spring calving pasture fed dairy systems. J. Dairy Sci. 99:59045915

Rotz, C. A., K. J. Soder, R. H. Skinner, C. J. Dell, P. J. Kleinman, J. P. Schmidt, and R. B. Bryant. 2009. Grazing can reduce the environmental impact of dairy production systems. Forage and Grazinglands. Accessed May 1, 2017. http://agris.fao.org/agris-search/ search.do? recordID $=$ US201301877155

Sayers, H. J., and C. S. Mayne. 2001. Effect of early turnout to grass in spring on dairy cow performance. Grass Forage Sci. 56:259-267.

Shalloo, L., P. Dillon, M. Rath, and M. Wallace. 2004. Description and validation of the Moorepark Dairy System Model. J. Dairy Sci. 87:1945-1959.

Vance, E. R., C. P. Ferris, C. T. Elliott, S. A. McGettrick, and D. J. Kilpatrick. 2012. Food intake, milk production, and tissue change of Holstein-Friesian and Jersey $\mathrm{x}$ Holstein-Friesian dairy cows within a medium input grazing system and a high input total confinement system. J. Dairy Sci. 95:1527-1544.

Wall Street Journal. 2014. Grass-fed milk is taking off with healthconscious shoppers. Accessed Apr. 21, 2017. https://www.wsj .com/articles/grass-fed-milk-is-taking-off-with-health-conscious -shoppers-1406675201.

Winsten, J. R., C. D. Kerchner, A. Richardson, A. Lichau, and J. M. Hyman. 2010. Trends in the Northeast dairy industry: Large-scale modern confinement feeding and management-intensive grazing. J. Dairy Sci. 93:1759-1769. 